\title{
Youth working in tobacco farming: effects on smoking behavior and association with health status
}

Ethel Alderete ${ }^{1}$, Jennifer Livaudais-Toman², Celia Kaplan², Steven E. Gregorich², Raúl Mejía ${ }^{3}$ and Eliseo J. Pérez-Stable $4^{*}$ (D)

\begin{abstract}
Background: Cultivation of tobacco raises concerns about detrimental health and social consequences for youth, but tobacco producing countries only highlight economic benefits. We compared sociodemographic and healthrelated characteristics of school-age youth who worked and did not work in tobacco farming and assessed the effects on smoking behavior and health at 1 year.
\end{abstract}

Methods: We used existing data collected in the province of Jujuy, Argentina where 3188 youth 13 to 17 years of age from a random middle school sample responded to longitudinal questionnaires in 2005 and 2006. Multivariate logistic regression models predicted association of tobacco farming work with health status and smoking behavior at 1 year.

Results: $22.8 \%$ of youth in the tobacco growing areas of the province were involved in tobacco farming. The mean age of initiation to tobacco farming was 12.6 years. Youth working in farming had higher rates of fair or poor versus good or excellent self-perceived health (30.3\% vs. $19.0 \%)$, having a serious injury (48.5\% vs. $38.5 \%)$, being injured accidentally by someone else (7.5\% vs. $4.6 \%$ ), being assaulted (5.5\% vs. $2.6 \%$ ), and being poisoned by exposure to chemicals (2.5\% vs. $0.7 \%)$. Youth working in tobacco farming also had higher prevalence of ever (67.9\% vs. $55.2 \%)$, current (48.0\% vs. $32.6 \%)$ and established smoking (17.8\% vs. 9.9\%). In multivariate logistic regression models tobacco farming in 2005 was associated with significant increased reporting of serious injury $(\mathrm{OR}=1.4 ; 95 \% \mathrm{Cl} 1.1-$ 2.0), accidental injury by someone else $(\mathrm{OR}=1.5 ; 95 \% 1.0-2.1)$, assault $(\mathrm{OR}=2.2 ; 95 \% \mathrm{Cl} 1.3-3.8)$, and poisoning by exposure to chemicals $(\mathrm{OR}=2.5 ; 95 \% \mathrm{Cl} 1.2-5.4)$. Tobacco farming in 2005 predicted established smoking 1 year later $(\mathrm{OR}=1.5 ; 95 \% \mathrm{Cl} 1.1-2.0)$.

Conclusion: Youth who work in tobacco faming face a challenging burden of adversities that increase their vulnerability. Risk assessments should guide public policies to protect underage youth working in tobacco farming. (298 words).

Keywords: Tobacco farming, Youth, Smoking, Health Status, Interagency Policy Making

\footnotetext{
* Correspondence: eliseo.perez-stable@nih.gov

${ }^{4}$ Division of Intramural Research, National Heart, Lung and Blood Institute, and Office of the Director, National Institute on Minority Health and Health Disparities, National Institutes of Health, 6707 Democracy Boulevard, Suite 800, Bethesda, MD 20892, USA

Full list of author information is available at the end of the article
}

(c) The Author(s). 2020 Open Access This article is distributed under the terms of the Creative Commons Attribution 4.0 International License (http://creativecommons.org/licenses/by/4.0/), which permits unrestricted use, distribution, and reproduction in any medium, provided you give appropriate credit to the original author(s) and the source, provide a link to the Creative Commons license, and indicate if changes were made. The Creative Commons Public Domain Dedication waiver (http://creativecommons.org/publicdomain/zero/1.0/) applies to the data made available in this article, unless otherwise stated. 


\section{Background}

Child labor is regarded as the employment of children less than 18 years of age [1]. It is associated with poverty, inadequate educational opportunities, gender inequality, and a variety of health risks as many are involved in hazardous occupations [2-5]. Children who work have higher rates of mortality, malnutrition and disability compared with those who do not work [6]. An estimated 6 million work-related injuries occur among children that result in 2.5 million becoming disabled and 32,000 fatalities each year [7]. Working children are more susceptible to harm from exposures than adults $[8,9]$ and more susceptible to emotional and physical abuse and drug addictions [10, 11].

Widespread cultivation of tobacco leaf has raised diverse public health issues including concern for child labor and for occupational health hazards. Children contribute significantly to the tobacco farming workforce in low and middle income countries [12]. In this occupation they are exposed to unsuitable working conditions and toxic chemicals [13]. Pesticides can cause skin and eye irritation, nerve damage, and respiratory symptoms. Dermal absorption of nicotine from contact with wet tobacco leaves can cause green tobacco sickness [14, 15]. Other health effects associated with tobacco farming include, respiratory disorders, musculoskeletal injuries and psychiatric disorders [16-20].

Van Minh et al. (2009) [21] conducted a survey among tobacco and non-tobacco farmers in Vietnam. The occurrence of 9 out of the 16 health problems was higher among tobacco farmers. Tobacco farming was the second predictor of self-reported health problems after the effect of age, placing these workers at increased risk of injury and illness. Similarly, Le Cai (2012) [22] conducted a cross-sectional survey among 8681 adults aged $\geq 18$ years in rural areas of the Yunnan Province, China from 2010 to 2011. Tobacco farmers had higher rates of current smoking, nicotine dependence, and second-hand smoke exposure compared with farmers not engaged in tobacco farming. Most tobacco users (84.5\%) reported initiating smoking during adolescence.

In the past 20 years, the tobacco production in Argentina has grown and the country is among the top six worldwide. In $2009 / 2010$ the production reached 132,869 tons, with $37.2 \%$ produced in the province of Jujuy. However, the tobacco farming labor force represents highly vulnerable sectors of the population facing poor living and working conditions [23]. More than 50\% of the total production is exported in the form of tobacco leaf. In May 2003, Argentina signed the Framework Convention on Tobacco Control, but the agreement has still not been ratified by the National Congress. Nevertheless, in 2007 the National Program for Tobacco Control was established within the Ministry of Health.
Several national and local tobacco control laws have been enacted, including the ban on selling tobacco to minors, the regulation of tobacco product advertising and promotion, and indoor tobacco consumption in public places. Regarding child labor, the country has ratified ILO Convention 138 Concerning Minimum Age for Admission to Employment. The Law 26,390 raised from 14 to 16 years the legal age for employment and set special protection for employees between 16 and 18 years of age [24, 25].

There is currently a gap in the state of the knowledge regarding the relationship between tobacco farming and smoking among underage youth in Latin America. This study evaluates the role of working in tobacco farming on tobacco use behavior among underage youth attending schools in the province of Jujuy. The research questions addressed in this analysis were the following: 1 . Are the sociodemographic characteristics of youth who work in tobacco farming different from peers not working in tobacco farming? 2. Are indicators of selfreported health status worse among youth working in tobacco farming? 3. Is there an effect of working in tobacco on smoking behaviors at 1 year of follow-up?

\section{Methods}

\section{Setting}

The Province of Jujuy, Argentina is characterized by a geographic configuration that includes lowlands where tobacco farms are located. Tobacco farming is an important contributor to the economy of the province, with 120 to 130 workdays by farmed hectare. The majority of the tobacco workforce in Jujuy are individuals hired by mid to large scale farmers. Only $1 \%$ are small farms with less than 2 ha of land that depend solely on family labor $[26,27]$.

\section{Sampling}

Secondary schools were randomly sampled from within the three geographic areas of Jujuy. Secondary schools include 8th through 12th grades and reflect the standard educational organization in Argentina. Based upon government data, we selected a representative sample of schools containing approximately 1000 eighth grade students from within each geographic area (i.e., disproportionate stratification). The final sample included 27 schools, three of which were private. The baseline data was collected in 2004 $(N=4276)$ among all enrolled 8th grade students, and three follow up surveys were conducted between 2005 and 2007. The response rate for each follow up was $94.2,91.7$ and $80.0 \%$ respectively. Surveys were self-administered in class with research staff and school coordinators present as proctors. In each school, one attempt was made to survey absent students at a subsequent date. The detailed study procedures have 
been described in a previous publication [28]. For this report we used data from the 3234 students between ages 13 and 17 years who completed surveys in 2005 (T1) and 2006 (T2). Of these, 46 (1.4\%) did not answer the questions about tobacco farming, yielding a total sample of 3188. The UCSF Committee on Human Research and an NIH-certified human subjects research board in Buenos Aires based at Centro de Educación Médica e Investigaciones Clínicas (CEMIC) approved the research protocol. Passive consent was requested from caretakers and students signed an active consent.

\section{Questionnaire development}

The questionnaire consisted of translated items from surveys of adolescents in the U.S. [29], and questions developed through qualitative research in the target population [28]. Items in English were translated and reviewed by three Argentinean investigators and two other Spanish-speaking research staff. Pilot testing of the instrument was conducted with students in rural and urban areas evaluating situational factors, content, characteristics of the respondents, and time of administration that averaged $1 \mathrm{~h}$.

\section{Demographics}

Sociodemographic variables were extracted from baseline data including sex, age, ethnicity (Indigenous, mixed Indigenous and European, European), and religion. Religion was categorized as Catholic, Christian or Evangelical, and others corresponding to low frequency religions. A binary (yes/no) low socioeconomic status (SES) variable was developed by classifying the primary caretaker as having up to primary education, being unemployed, or being on welfare, versus having a higher education level or being formally employed. The location of the school was reported in the questionnaire by interviewers.

\section{Health related factors}

Health related variables correspond to T1 responses. Respondents provided a self-assessment of their health status, categorized as excellent, good, fair or poor. Another set of questions probed on the occurrence of injuries. We asked if in the previous year respondents had a serious injury, if they were injured accidentally by someone else, if they had been assaulted, and if they had been poisoned by exposure to chemical products. Local agricultural workers commonly refer to pesticides as "chemicals" and the survey question was phrased accordingly.

\section{Smoking behavior}

For this study, we used smoking information from T1 (2005) and T2 (2006). Smoking behavior was the main outcome and questions were developed to be comparable to those used in the Centers for Disease Control and Prevention GYTS survey [29]. Respondents were considered ever smokers if they tried at least a cigarette puff in their lifetime and never smokers had not tried even one puff. Current smokers were defined as having smoked at least one whole cigarette in their lifetime and at least one puff in the previous 30 days. Established smokers were defined as current smokers who had smoked at least 100 cigarettes in their lifetime. Respondents also reported on the number of friends who smoked (none, 1 to 4,5 or more), and whether any adult smoked in their home.

\section{Working in tobacco farming}

Hereby reported exposure variables correspond to measurements at T1. The youth were asked if they had ever worked in any of the tasks involved in tobacco production, growing, harvesting or selecting tobacco leaf, without discriminating the different types of tasks. Youth reported their age of initiation in tobacco farming work. Information about working in non-tobacco farming occupations was also requested.

\section{Data analysis}

The sampling design was incorporated into all models by specifying geographic areas as strata and schools as clusters as well as including weights to adjust for disproportionate stratification. In addition, a finite population correction was applied to adjust for the relatively large proportion of available schools sampled within each geographic area. The statistical program Stata (version 14.2) was used for data analysis. Standard errors and confidence intervals were estimated via the Taylor expansion approximation using the svy procedures in Stata [30]. First, we conducted descriptive analyses by sex, to profile the sample. We calculated the prevalence of ever, current and established smoking, with chi square tests and $p$ values at T1 and T2, and the percentage of youth who reported at $\mathrm{T} 1$ that they had ever worked in tobacco and non- tobacco farming. The mean and standard deviation of the age for girls and boys, and of the age of initiation in tobacco farming was calculated. Bivariate contingency tables examined the pairwise relationship of sociodemographic characteristics, health related factors and smoking behavior by sex, and by working in tobacco farming. Bivariate analysis also examined the pairwise relationship of non-tobacco farming and the smoking behavior variables.

Multivariate logistic models regressed working in tobacco farming at T1 with each of the health-related variables at T1. Separate multivariate logistic models regressed working in tobacco farming at $\mathrm{T} 1$ onto cigarette smoking behaviors at T2 (ever, current or established smoking). Covariates included sociodemographic characteristics (sex, age, low SES, ethnicity, 
religion, number of friends who smoked, adult smokers at home, and for each model, the corresponding smoking behavior at T1 (ever, current or established smoking). We estimated adjusted odds ratios and 95\% confidence intervals.

\section{Results}

The mean age for girls was 14.5 years (95\% CI $14.4-$ 14.6) and for boys, 15.1 years (95\% CI 14.9-15.3) (data not shown). Low SES was more prevalent among girls than boys $(25.8 \%$ vs. $20 \%, p=0.006)$ and $71.7 \%$ of the girls self-identified as being Indigenous, compared with $65 \%$ of the boys $(p<0.001)$. A greater percentage of girls reported living with an adult who smoked at home (76.8\% vs. $73.2 \%, p=0.018$ ).

A greater percentage of girls perceived that their health status was fair or poor, compared with boys $(25.3 \%$ vs. $14.3 \%, p<0.001)$. However, boys were more likely to report serious injures $(46.9 \%$ vs. $33.5 \%, p<$ $0.001)$, being accidentally injured by someone else $(6.2 \%$ vs. $4.0 \%, p=0.002)$ and being assaulted $(4.5 \%$ vs. $1.6 \%$, $p<0.001$ ) (Table 1). At T1 (2005), the prevalence of ever (56.6\%) and current smoking (34.4\%) was similar for boys and girls but established smoking was more prevalent among boys $(13 \%$ vs. $8.9 \%, p=0.004)$. The prevalence of working in tobacco farming was unevenly distributed across geographical regions, involving $22.8 \%$ of youth in the lowlands where tobacco is cultivated, and between 4.5 to $4.9 \%$ in the other areas (data not shown). Ever working in tobacco farming was reported by $11.5 \%$ of the total sample (Table 1 ). Involvement in tobacco farming was more prevalent among boys $(12.9 \%$ vs. $10.3 \%, p=0.044)$ but the mean age of initiation did not differ significantly between girls $(12.0$; $95 \%$ CI 11.4 13.0) and boys (12.7; 95\% CI 12.1-13.2).

\section{Tobacco farming sociodemographic, health factors and smoking behavior}

The percentage of youth who endorsed an evangelical religion was greater among those who worked in tobacco farming ( $17.0 \%$ vs. 9.8\%). Working in tobacco farming was also associated with having low SES (28.5\% vs. $22.4 \%$ ), being Indigenous ( $77.8 \%$ vs. $67.4 \%)$, and having more than 5 friends who smoked (60.6\% vs. $46.7 \%)$.

Among youth working in tobacco farming $30.3 \%$ reported perceiving that their health was fair or poor, compared with $19.0 \%$ of other youth $(p=0.004)$. Tobacco farming was also associated with having a serious injury $(48.5 \%$ vs. $38.5 \%, p=0.004)$, being injured accidentally by someone else ( $7.5 \%$ vs. $4.6 \%, p=0.01$ ), being assaulted ( $5.5 \%$ vs. $2.6 \%, p=0.008)$, and being poisoned by chemical products $(2.5 \%$ vs. $0.7 \%, p=0.003)$.

Youth who had ever worked in tobacco farming had significantly higher prevalence of ever smoking $(67.9 \%$ vs. $55.2 \%, p<0.001)$, current smoking $(48.0 \%$ vs. $32.6 \%$, $\mathrm{p}<0.001)$ and established smoking $(17.8 \%$ vs. $9.9 \%, p=$ $0.002)$ at T1 (2005). The prevalence of smoking behaviors increased slightly at T2 (2006) for the total sample. Although smoking rates decreased slightly among youth working in tobacco farming from $\mathrm{T} 1$ to $\mathrm{T} 2$, they remained significantly higher compared to those who did not work (Table 2). Smoking rates did not differ significantly between youth working any non-tobacco farming job compared to those not working at all for ever smoking ( $64 \%$ vs. $58 \%, p=0.118$ ), for current smoking (39\% vs. $35 \%, p=0.087)$ or for established smoking $(14 \%$ vs. $11 \%, p=0.189$ ) (data not shown).

\section{Effects of exposure to tobacco farming: multivariate analysis}

In multivariate logistic regression models working in tobacco farming in 2005 significantly increased the likelihood of having a serious injury, being injured accidentally by someone else, being assaulted or being poisoned by chemical products in the same year (Table 3). In another set of multivariate logistic regression models, tobacco farming in 2005 predicted established smoking 1 year later (2006) $(\mathrm{OR}=1.5 ; 95 \%$ CI 1.1.-2.0) (Table 4). Tobacco farming in 2005 was not predictive of ever or current smoking in 2006 although the point estimate was in the increased odds direction. Significant risk factors for established smoking were, religion other than catholic or evangelical, mixed Indigenous-European ethnicity, and having 5 or more friends who smoked versus none (data not shown). Separate logistic models including interaction terms between tobacco farming and sex, ethnicity, and having friends who smoked, yielded no significant interaction effects (data not shown).

\section{Discussion}

The sociodemographic profile of these Jujuy youth working in tobacco farming highlights the roots of the child labor problem at a global level, involving youth belonging to poor families and of non-dominant social groups, particularly Indigenous populations. Our results highlight that socioeconomically vulnerable youths may be further impaired in their development by occupational health problems and the increased risk of cigarette smoking associated with a large set of health risks throughout the life course [13]. Furthermore, youth who worked in tobacco farming reported having a fair or poor self-reported health status in a greater proportion than other youth, as well as increased rates of exposure to toxic chemicals. Although we cannot ascertain the precise nature of sustained injuries, or a direct relation to the occupational context, we identified an increased risk of exposure to violence through assaults among youth working in tobacco farming. The increased 
Table 1 Sociodemographic characteristics of 3188 Youth by sex, Jujuy, Argentina, 2005 I

\begin{tabular}{|c|c|c|c|c|}
\hline & Girls N (\%) N=1739 & Boys $N(\%) N=1495$ & Total $N(\%) N=3234$ & $p$ value \\
\hline \multicolumn{5}{|l|}{ Sociodemographic characteristics } \\
\hline LOW SES & $457(25.8)$ & $314(20.0)$ & $771(23.1)$ & $0.006^{*}$ \\
\hline \multicolumn{5}{|l|}{ Ethnicity } \\
\hline Indigenous & $1215(71.7)$ & $975(65.0)$ & $2190(68.6)$ & \multirow[t]{3}{*}{$0.001^{*}$} \\
\hline Mixed Indigenous/European & $342(21.5)$ & $307(22.8)$ & $649(22.1)$ & \\
\hline European & $101(6.8)$ & $150(12.1)$ & $251(9.3)$ & \\
\hline \multicolumn{5}{|l|}{ Religion } \\
\hline Catholic & $1461(85.2)$ & $1248(85.1)$ & $2709(85.1)$ & \multirow[t]{3}{*}{0.887} \\
\hline Evangelical & $186(10.8)$ & $159(10.4)$ & $345(10.6)$ & \\
\hline Other & $67(4.0)$ & $67(4.5)$ & $134(4.2)$ & \\
\hline \multicolumn{5}{|l|}{ Number of friends who smoke } \\
\hline None & $454(27.6)$ & $320(23.4)$ & $774(25.7)$ & \multirow[t]{3}{*}{0.056} \\
\hline $1-4$ & $446(27.1)$ & $345(24.8)$ & $791(26.1)$ & \\
\hline $5+$ & $720(45.3)$ & $724(51.8)$ & $1444(48.3)$ & \\
\hline Adult smokers at home & $1314(76.8)$ & $1076(73.2)$ & $2390(75.2)$ & $0.018^{*}$ \\
\hline \multicolumn{5}{|l|}{ Health variables } \\
\hline \multicolumn{5}{|l|}{ Perceived health } \\
\hline Excellent/good & $1232(74.7)$ & $1240(85.7)$ & $2472(79.7)$ & \multirow[t]{2}{*}{$0.001^{*}$} \\
\hline Fair/poor & $479(25.3)$ & $225(14.3)$ & $704(20.3)$ & \\
\hline Serious injury & $590(33.5)$ & $678(46.9)$ & $1268(39.6)$ & $0.001^{*}$ \\
\hline Accidental injury by someone else & $67(4.0)$ & $97(6.2)$ & $164(5.0)$ & $0.002^{*}$ \\
\hline Assaulted & $28(1.6)$ & $64(4.5)$ & $92(2.9)$ & $0.001^{*}$ \\
\hline Poisoned by chemical products & $11(0.8)$ & $17(1.0)$ & $28(0.9)$ & 0.452 \\
\hline \multicolumn{5}{|l|}{ Smoking Prevalence T1 (2005) } \\
\hline Ever smoker & $969(57.0)$ & $841(56.2)$ & $1810(56.6)$ & 0.691 \\
\hline Current smoker & $561(33.7)$ & $521(35.1)$ & $1082(34.4)$ & 0.7181 \\
\hline Established smoker & $146(8.9)$ & $194(13.0)$ & $340(10.8)$ & $0.004^{*}$ \\
\hline \multicolumn{5}{|l|}{ Tobacco farming } \\
\hline Ever worked in Tobacco Farming & $190(10.3)$ & $193(12.9)$ & $383(11.5)$ & \multirow[t]{2}{*}{$0.044^{*}$} \\
\hline Age started working in tobacco farming, Mean years $(95 \% \mathrm{Cl})$ & $12.0(11.4-13.0)$ & $12.7(12.1-13.2)$ & $12.2(11.8-12.6)$ & \\
\hline
\end{tabular}

* Chi square test, $p$ value

exposure to interpersonal violence finding has not been reported in other studies, largely of adult populations. As a primary finding we ascertained a one-year effect of work in tobacco farming among youth, on being an established smoker defined as current smoker of at least 100 cigarettes lifetime. To our knowledge, this finding has not been previously reported and is unique in focusing on underage youth.

Prior research postulates that there may be an association between exposure to pesticides and mental health problems [31-35], and smoking has been associated to psychological distress among adolescents [36]. On this basis, future research could investigate the mediating role of mental health status on smoking among youth who work in tobacco farming. In addition, violence, and its associated stress, may trigger increased desire to smoke linked to coping mechanisms [37]. Not only does working in tobacco farming increase the risk of established smoking, but tobacco related illnesses caused by smoking may be compounded by the occupational hazards of tobacco farming. For example, respiratory illnesses caused by particles and microorganisms growing on tobacco leaves may exacerbate damage to lung cells $[19,18]$. Future studies should evaluate synergistic adverse health effects between smoking and occupational hazards in tobacco farming.

This study's strengths include the population-based sampling strategy which enhances the generalization of results. The repeated sampling of participants between 2005 and 2006 was useful for examining longitudinal 
Table 2 Sociodemographic and health factors associated with tobacco farming in 3188 Youth, Jujuy, Argentina, 2005-2006

\begin{tabular}{|c|c|c|c|c|}
\hline & \multicolumn{4}{|l|}{ Tobacco Farming } \\
\hline & No $N(\%) N=2805$ & Yes $N(\%) N=383$ & Total $N(\%) N=3188$ & Chi square $p$ value \\
\hline \multicolumn{5}{|l|}{ Sociodemographic characteristics } \\
\hline Sex & & & & 0.044 \\
\hline Girls & $1524(55.0)$ & $190(48.7)$ & $1714(54.3)$ & \\
\hline Boys & $1281(45.0)$ & $193(51.3)$ & $1474(45.7)$ & \\
\hline Religion & & & & 0.003 \\
\hline Catholic & $2408(86.0)$ & $301(78.3)$ & $2709(85.1)$ & \\
\hline Evangelical & $280(9.8)$ & $65(17.0)$ & $345(10.6)$ & \\
\hline Other & $117(4.2)$ & $17(4.7)$ & $134(4.2)$ & \\
\hline LOW SES & $660(22.4)$ & $111(28.5)$ & $771(23.1)$ & 0.023 \\
\hline Ethnicity & & & & 0.034 \\
\hline Indigenous & $1899(67.4)$ & $291(77.8)$ & $2190(68.6)$ & \\
\hline Mixed Indigenous/European & $582(22.6)$ & $67(18.3)$ & $649(22.1)$ & \\
\hline European & $237(9.9)$ & $14(3.9)$ & $251(9.3)$ & \\
\hline Number of friends who smoke & & & & 0.001 \\
\hline None & $711(26.7)$ & $63(17.6)$ & $774(25.7)$ & \\
\hline $1-4$ & $710(26.6)$ & $81(22.0)$ & $791(26.1)$ & \\
\hline $5+$ & $1231(46.7)$ & $213(60.4)$ & $1444(48.3)$ & \\
\hline Adult smokers at home & $2102(75.2)$ & $288(74.6)$ & $2390(75.2)$ & 0.089 \\
\hline \multicolumn{5}{|l|}{ Health variables } \\
\hline Perceived health & & & & 0.004 \\
\hline Excellent & $1247(47.4)$ & $111(30.9)$ & $1358(45.5)$ & \\
\hline Good & 964 (33.6) & $150(38.8)$ & $1114(34.2)$ & \\
\hline fair/poor & $586(19.0)$ & $118(30.3)$ & $704(20.3)$ & \\
\hline Had a serious injury & $1092(38.5)$ & $176(48.5)$ & $1268(39.6)$ & 0.004 \\
\hline Injured accidentally by someone else & $137(4.6)$ & $27(7.5)$ & $164(5.0)$ & 0.010 \\
\hline Assaulted & $75(2.6)$ & $17(5.5)$ & $92(2.9)$ & 0.008 \\
\hline Poisoned by chemical products & $8(0.7)$ & $0(2.5)$ & $28(0.9)$ & 0.003 \\
\hline \multicolumn{5}{|l|}{ Smoking Behavior T1 (2005) } \\
\hline Ever smoker & $1553(55.2)$ & $257(67.9)$ & $1810(56.6)$ & 0.001 \\
\hline Current smoker & 905 (32.6) & $177(48.0)$ & $1082(34.4)$ & 0.001 \\
\hline Established smoker & $276(9.9)$ & $64(17.8)$ & $340(10.8)$ & 0.002 \\
\hline \multicolumn{5}{|l|}{ Smoking Behavior T2 (2006) } \\
\hline Ever smoker & $1516(58.9)$ & $237(68.8)$ & $1753(60.0)$ & 0.001 \\
\hline Current smoker & $855(34.0)$ & $153(44.9)$ & $1008(35.2)$ & 0.001 \\
\hline Established smoker & $276(11.1)$ & $58(17.5)$ & $334(11.9)$ & 0.002 \\
\hline
\end{tabular}

Table 3 Exposure to Tobacco Farming associated with Health Outcomes Jujuy, Argentina, 2005

\begin{tabular}{llllll}
\hline Logistic Regression of Exposure to Tobacco Farming in 2005 and Health & Outcomes in 2005, for Health-related Outcomes & \\
\hline & $\begin{array}{l}\text { Perceived Health Status Excellent/ } \\
\text { Good vs. Fair/poor OR (95\% Cl) }\end{array}$ & $\begin{array}{l}\text { Serious Injury Yes } \\
\text { vs. No OR (95\% Cl) }\end{array}$ & $\begin{array}{l}\text { Accidental Injury by Someone } \\
\text { Else Yes vs. No OR (95\% Cl) }\end{array}$ & $\begin{array}{l}\text { Assault Yes vs. } \\
\text { No OR (95\% Cl) }\end{array}$ & $\begin{array}{l}\text { Chemical poisoning vs. No OR (95\% Cl) } \\
\text { Yes vo }\end{array}$ \\
\hline Tobacco & $0.7(0.5-1.0)$ & $1.4(1.1-2.0)^{*}$ & $1.5(1.0-2.1)^{*}$ & $2.2(1.3-3.8)^{* *}$ & $2.5(1.2-5.4)^{* *}$ \\
Farming & & & &
\end{tabular}


Table 4 Exposure to Tobacco Farming in 2005 Effects on Smoking Behavior in 2006, Jujuy, Argentina, 2005-2006

Logistic Regression of Exposure to Tobacco Farming in 2005 as a Predictor of Smoking Behaviors in 2006

\begin{tabular}{llll}
\hline & Ever Smoker Yes vs. No OR $(95 \%$ Cl) & Current Smoker Yes vs. No OR $(95 \%$ Cl) & Established smoker Yes vs. No OR (95\% Cl) \\
\hline Tobacco Farming & $1.2(0.9-1.7)$ & $1.2(0.8-1.6)$ & $1.5(1.1-2.0)^{* *}$ \\
\hline
\end{tabular}

Logistic regression models (3.a. and 3.b.) controlling for age, sex, ethnicity, religion, low SES status, number of friends who smoke, adult smokers at home, and smoking at $\mathrm{T} 1$

${ }^{*} p \leq 0.05 ;{ }^{* *} p \leq 0.01$

effects of tobacco farming. However, with this dataset we were not able to determine a precise date of initiation in tobacco farming to calculate a time of exposure variable, as this information is based on recall and it is not unusual for children to become involved in this activity at very early ages. Likewise, we were not able to determine the type of tasks performed and the amount of time in months and years of previous exposure or if respondents were still working in tobacco farming at the time of the study. The inclusion of youth with less exposure time to tobacco farming work would potentially reduce the effect of the exposure and bias results towards the null. Therefore, we are presenting conservative results. Although the one-year time frame used for this analysis is a limitation and was based on the fact that tobacco farming work questions were not consistently included in all waves of the study. In addition, we cannot ascertain that injuries and poisoning with chemicals occurred while conducting tobacco farming activities. Another limitation is that we are not able to draw causal inference about health-related factors since the health data used for this analysis was collected at only one time point. Although the data were collected more than 10 years ago, the practice of hiring underage youth in tobacco farming is a current practice [38].

More than 250,000 hectares of tobacco are planted throughout the globe in more than a 100 countries [39]. However, the governments of tobacco producing countries largely view tobacco cultivation as an important contributor to the national economy by generating tax revenues, employment and income in otherwise deprived areas, while overlooking labor rights and health issues, including the economic costs of illness and social problems related to tobacco farming [38].

This report contributes to breaching the knowledge gap of the longitudinal effect of tobacco farming on smoking behavior among youth. In addition, poor selfperceived health, more accidents and exposure to violent settings in this population, highlights the need to develop structural mechanisms to protect youth from the often overlooked social and health risks involved in tobacco farming. In the process of setting national economic priorities and policies, state agencies other than those pertaining to the economic sector, namely health, social work, education, environmental and other related agencies, practitioners and scholars should be called upon to contribute to diagnostic assessments and policy formulations that take into account the complex nature of tobacco farming.

\section{Conclusions}

Tobacco farming work by underage youth in the Province of Jujuy, Argentina is associated with adverse health events, worse perceived health status and greater odds of becoming established smokers. Risk assessments should guide public policies to protect underage youth working in tobacco farming through structural change and enforcement of existing regulations.

\section{Abbreviations}

CEMIC: Centro de Educación Médica e Investigaciones Clínicas; OR: Odds Ratio; T1: Time 1; T2: Time 2; UCSF: University of California, San Francisco; SES: Socioeconomic status

\section{Acknowledgments}

The authors acknowledge the participants, the teachers and school principals who collaborated with the surveys. Research assistants supervised all data collection and data entry for analysis. Contents and views in this manuscript are those of the authors and should not be construed to represent the views of the National Institutes of Health.

\section{Authors' contributions}

EA conceptualized the paper focus and analysis strategy, contributed significantly to writing the final version of the manuscript. JLT conducted the data analysis and contributed to the methodology and results sections. EPS was the Principal Investigator of the original grant, contributed significantly to writing the final version of the manuscript, the conceptualization of paper focus and the analysis development. CK, SG and RM participated in the design of the study and helped revise the manuscript. All authors read and approved the final manuscript.

\section{Funding}

This research was funded by Grant no. TW05935 from the Tobacco Research Network Program, Fogarty International Center, National Cancer Institute, National Institute of Drug Abuse, National Institutes of Health and by Grant no. 001726-037 from Research on International Tobacco Control, International Development Research Center, Canada. The funding institutions had no role in the design of the study, collection and analysis of the data, or interpretation of the results and in writing of the manuscript.

\section{Availability of data and materials}

The datasets used and/or analyzed during the current study are available from the corresponding author upon request.

\section{Ethics approval and consent to participate}

The UCSF Committee on Human Research and an NIH-certified human subjects research board in Buenos Aires based at CEMIC approved the research protocol. Passive consent was requested from caretakers and students signed an active consent. 


\section{Competing interests}

The authors declare that they have no competing interests.

\section{Author details}

'Instituto de Ciencia y Tecnología Regional (ICTER), UE CISOR Consejo Nacional de Investigaciones Científicas y Técnicas/Universidad Nacional de Jujuy, San Salvador de Jujuy, Argentina. ${ }^{2}$ Division of General Internal Medicine, Department of Medicine, University of California, San Francisco, USA. ${ }^{3}$ Centro de Estudios de Estado y Sociedad (CEDES), Buenos Aires, Argentina. ${ }^{4}$ Division of Intramural Research, National Heart, Lung and Blood Institute, and Office of the Director, National Institute on Minority Health and Health Disparities, National Institutes of Health, 6707 Democracy Boulevard, Suite 800, Bethesda, MD 20892, USA.

\section{Received: 28 August 2019 Accepted: 7 January 2020} Published online: 20 January 2020

\section{References}

1. Landrigan PJ, Pollack SH, Belville R, Godbold JH. Child labor. Pediatr Ann. 1995:24:657-62. https://doi.org/10.3928/0090-4481-19951201-10.

2. Parker D. Child labor. The impact of economic exploitation on the health and welfare of children. Minn Med. 1997:80:10 12-3-52-5 https://www. popline.org/node/269320. Accessed 12 Mar 2019.

3. Roggero P, Mangiaterra V, Bustreo F, Rosati F. The health impact of child labor in developing countries: evidence from cross-country data. Am J Public Health. 2007:97:271-5. https://doi.org/10.2105/AJPH.2005.066829.

4. Grosky S. Abordaje contra el trabajo infantil desde el Mercosur. Buenos Aires; 2015. www.lo.org/buenosaires. Accessed 20 Feb 2019.

5. Fassa A, Parker DL (David L, Scanlon TJ. Child labour : a public health perspective. Oxford University Press; 2010. https://books.google.com.ar/ books?hl=es\&lr=\&id=NB4ZXSftczOC\&oi=fnd\&pg=PR9\&dq=Parker+D+and+ Health+effect+on+child+labor\&ots=HTutC4yHjA\&sig=

ZcWJgthECciNLbyR9oxWul690Kg\#v=onepage\&q=Parker D and Health effect on child labor\&f=false. Accessed 12 Mar 2019.

6. Vassar M, Holzmann M. The retrospective chart review: important methodological considerations. J Educ Eval Health Prof. 2013;10:12. https:// doi.org/10.3352/jeehp.2013.10.12.

7. Graitcer PL, Lerer LB. Child Labor and Health: Quantifying the Global Health Impacts of Child Labor. World Bank, 1818 H Street, N.W., Washington, DC 20433. Tel: 202-473-3427; Fax: 202-522-3233.; 1998. https://eric.ed.gov/?id= ED438095. Accessed 21 Feb 2019

8. National Research Council. Pesticides in the Diets of Infants and Children. Washington: National Academies Press; 1993. https://doi.org/10.17226/2126.

9. Volkow ND, Koob GF, Croyle RT, Bianchi DW, Gordon JA, Koroshetz WJ, et al The conception of the ABCD study: from substance use to a broad $\mathrm{NIH}$ collaboration. Dev Cogn Neurosci. 2018;32:4-7. https://doi.org/10.1016/j.den. 2017.10.002

10. Briceño Ayala L, Pinzón Rondón ÁM. Efectos del trabajo infantil en la salud del menor trabajador. Rev Salud Pública. 2004;6:270-88. https://doi.org/10. 1590/S0124-00642004000300004

11. Dall'Agnol MM, Fassa ACG, Facchini LA. Child and adolescent labor and smoking: a cross-sectional study in southern Brazil. Cad Saude Publica. 2011; 27:46-56. https://doi.org/10.1590/S0102-311X2011000100005.

12. Ramos AK. Child labor in global tobacco production: a human rights approach to an enduring dilemma. Health Hum Rights. 2018;20:235-48 http://www.ncbi.nlm.nih.gov/pubmed/30568417. Accessed 10 Jul 2019.

13. Drope J, Schluger N, Cahn Z, Drope J, Hamill S, Islami F, et al. Tobacco atlas. 6th ed. Atlanta: MCGRAW-HILL EDUCATION; 2018.

14. McKnight RH, Spiller HA. Green tobacco sickness in children and adolescents. Public Health Rep. 2005;120:602-5. https://doi.org/10.1177/ 003335490512000607

15. Fassa AG, Faria NMX, Meucci RD, Fiori NS, Miranda VI, Facchini LA. Green tobacco sickness among tobacco farmers in southern Brazil. Am J Ind Med. 2014:57:726-35. https://doi.org/10.1002/ajim.22307.

16. Riquinho DL, Hennington EA. Health, environment and working conditions in tobacco cultivation: a review of the literature. Cien Saude Colet. 2012;17: 1587-600. https://doi.org/10.1590/S1413-81232012000600022.

17. Arcury TA, Quandt SA. Health and social impacts of tobacco production. J Agromedicine. 2006;11:71-81. https://doi.org/10.1300/J096v11n03_08.

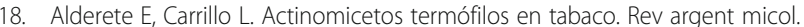
1988;11:13-5 http://bases.bireme.br/cgi-bin/wxislind.exe/iah/online/
?lsisScript=iah/iah $. x i s \& s r c=$ google\&base $=$ LILACS\&lang=p\&nextAction $=$ Ink\&exprSearch=70585\&indexSearch=ID. Accessed 12 Mar 2019.

19. Fiori NS, Fassa AG, Faria NMX, Meucci RD, Miranda VI, Christiani DC. Wheezing in tobacco farm workers in southern Brazil. Am J Ind Med. 2015; 58:1217-28. https://doi.org/10.1002/ajim.22447.

20. Lecours N, Almeida GEG, Abdallah JM, Novotny TE. Environmental health impacts of tobacco farming: a review of the literature. Tob Control. 2012;21: 191-6. https://doi.org/10.1136/tobaccocontrol-2011-050318.

21. Van Minh H, Giang KB, Bich NN, Huong NT. Tobacco farming in rural Vietnam: questionable economic gain but evident health risks. BMC Public Health. 2009:9:24. https://doi.org/10.1186/1471-2458-9-24.

22. Cai L, Wu X, Goyal A, Han Y, Cui W, Xiao X, et al. Patterns and socioeconomic influences of tobacco exposure in tobacco cultivating rural areas of Yunnan Province, China. BMC Public Health. 2012;12:842. https:// doi.org/10.1186/1471-2458-12-842.

23. Arrueta M. Población socio laboral del tabaco jujeño. La vulnerabilidad en el desarrollo agrario local. Rev Nuestro NOA. 2017;10:151-66 http://www.fhycs. unju.edu.ar/documents/publicaciones/nuestronoa/NUESTRONOA10. pdf\#page=147. Accessed 12 Mar 2019.

24. Cutri A, Hammermüller A, Zubieta A, Müller Opeta B, Miguelez L. Trabajo infantil: una problemática social que nos compromete. Arch Argent Pediatr. 2012;110:350-8. https://doi.org/10.5546/aap.2012.350.

25. Atanasof A. El trabajo infantil en Argentina. Corregidor: Buenos Aires; 2001. http://redbiblio.unne.edu.ar/pdf/0101-031715_l.pdf. Accessed 13 Mar 2019

26. Diez MC, Re DA. El complejo agroindustrial tabacalero: un análisis sobre las transformaciones socioproductivas en las provincias argentinas de Jujuy y Misiones. Rev Antropolítica. 2018;39. https://doi.org/10.22409/ ANTROPOLITICA.VOI39.

27. Re A. Los actores sociales en el agro. Buenos Aires: La provincia de Jujuy y la producción de tabaco Virginia; 2009. https://www.aacademica.org/000089/345. Accessed 13 Mar 2019

28. Alderete E, Kaplan CP, Gregorich SE, Mejía R, Pérez-Stable EJ. Smoking behavior and ethnicity in Jujuy, Argentina: evidence from a low-income youth sample. Subst Use Misuse. 2009:44:632-46. https://doi.org/10.1080/10826080902809717.

29. Global Youth Tabacco Survey Collaborative Group. Tobacco use among youth: a cross country comparison. Tob Control. 2002;11:252-70 http:// www.ncbi.nlm.nih.gov/pubmed/12198280. Accessed 12 Mar 2019.

30. StataCorp. StataCorp. 2015. Stata Statistical Software: Release... - Google Académico. 2015. https://scholar.google.com.ar/scholar?hl=es\&as_sdt=0\%2 C5\&q=StataCorp.+2015.+Stata+Statistical+Software\%3A+Release+14.+ College+Station\%2C+TX\%3A+StataCorp+LP.\&btnG=. Accessed 2 May 2019.

31. Faria NMX, Fassa AG, Meucci RD, Fiori NS, Miranda VI. Occupational exposure to pesticides, nicotine and minor psychiatric disorders among tobacco farmers in southern Brazil. Neurotoxicology. 2014;45:347-54. https://doi.org/10.1016/J.NEURO.2014.05.002.

32. Harrison V, Mackenzie RS. Anxiety and depression following cumulative lowlevel exposure to organophosphate pesticides. Environ Res. 2016;151:52836. https://doi.org/10.1016/j.envres.2016.08.020.

33. Koh S-B, Kim TH, Min S, Lee K, Kang DR, Choi JR. Exposure to pesticide as a risk factor for depression: a population-based longitudinal study in Korea. Neurotoxicology. 2017;62:181-5. https://doi.org/10.1016/j.neuro.2017.07.005.

34. Serrano-Medina A, Ugalde-Lizárraga A, Bojorquez-Cuevas M, Garnica-Ruiz J, González-Corral M, García-Ledezma A, et al. Neuropsychiatric disorders in farmers associated with Organophosphorus pesticide exposure in a Rural Village of Northwest México. Int J Environ Res Public Health. 2019;16:689. https://doi.org/10.3390/ijerph16050689.

35. Campos ÿlida, dos Santos Pinto da Silva V, Sarpa Campos de Mello M, Barros Otero U. Exposure to pesticides and mental disorders in a rural population of Southern Brazil. Neurotoxicology. 2016;56:7-16. https://doi. org/10.1016/j.neuro.2016.06.002.

36. Ferreira VR, Jardim TV, Sousa ALL, Rosa BMC, Jardim PCV. Smoking, alcohol consumption and mental health: data from the Brazilian study of cardiovascular risks in adolescents (ERICA). Addict Behav Reports. 2019;9: 100147. https://doi.org/10.1016/j.abrep.2018.100147.

37. Lazarus RS, Folkman S. Stress, appraisal, and coping. New York: Springer Publishing Co.; 1984. https://books.google.com.ar/books?hl=es\&lr=\&id=iySQQuUpr8C\&oi=fnd\&pg=PR5\&dq=stress+and+coping+and+lazarus\&ots= DfHOnuclNf\&sig=yU1YuKVSJ.pnCejiDTxcVXnXNcqU\#v=onepage \&q=stress and coping and lazarus\&f=false. Accessed 14 Mar 2019.

38. El Tribuno D. Emitieron 45 autorizaciones laboral es para adolescentes. https://www.eltribuno.com/jujuy/nota/2018-11-7-19-3-0-emitieron-45- 
autorizaciones-laboral-espara-adolescentes. 2018. https://www.eltribuno. com/jujuy/nota/2018-11-7-19-.

39. World Health Organization. Tobacco and poverty: A vicious circle. Geneva, Switzerland; 2004. https://apps.who.int/iris/bitstream/handle/10665/116428/ EMRPUB_2004_EN_773.pdf. Accessed 10 Jul 2019.

\section{Publisher's Note}

Springer Nature remains neutral with regard to jurisdictional claims in published maps and institutional affiliations.

Ready to submit your research? Choose BMC and benefit from:

- fast, convenient online submission

- thorough peer review by experienced researchers in your field

- rapid publication on acceptance

- support for research data, including large and complex data types

- gold Open Access which fosters wider collaboration and increased citations

- maximum visibility for your research: over $100 \mathrm{M}$ website views per year

At $\mathrm{BMC}$, research is always in progress. 